\title{
Direct evidence for mRNA binding and post-transcriptional regulation by Escherichia coli aconitases
}

\author{
Yue Tang and John R. Guest \\ Author for correspondence: John R. Guest. Tel: +44 114222 4406/3. Fax: +44 1142728697. \\ e-mail: j.r.guest@sheffield.ac.uk
}

The Krebs Institute for Biomolecular Research, Department of Molecular Biology and

Biotechnology, University of Sheffield, Western Bank, Sheffield S10 2TN, UK

\begin{abstract}
Escherichia coli contains a stationary-phase aconitase (AcnA) that is induced by iron and oxidative stress, and a major but less stable aconitase (AcnB) synthesized during exponential growth. These enzymes were shown to resemble the bifunctional iron-regulatory proteins (IRP1)/cytoplasmic aconitases of vertebrates in having alternative mRNA-binding and catalytic activities. Affinity chromatography and gel retardation analysis showed that the AcnA and AcnB apo-proteins each interact with the $3^{\prime}$ untranslated regions (3'UTRs) of acnA and acnB mRNA at physiologically significant protein concentrations. AcnA and AcnB synthesis was enhanced in vitro by the apoaconitases and this enhancement was abolished by 3'UTR deletion from the DNA templates, presumably by loss of acn-mRNA stabilization by bound apoaconitase. In vivo studies showed that although total aconitase activity is lowered during oxidative stress, synthesis of the AcnA and AcnB proteins and the stabilities of acnA and acnB mRNAs both increase, suggesting that inactive aconitase mediates a post-transcriptional positive autoregulatory switch. Evidence for an iron-sulphur-cluster-dependent switch was inferred from the more than threefold higher mRNA-binding affinities of the apo-aconitases relative to the holo-enzymes. Thus by modulating translation via site-specific interactions between apo-enzyme and relevant transcripts, the aconitases provide a new and rapidly reacting component of the bacterial oxidative stress response.
\end{abstract}

Keywords: conitase, mRNA stability, oxidative stress, post-transcriptional regulation, protein-mRNA interactions

\section{INTRODUCTION}

The aconitases convert citrate to isocitrate via cisaconitate in the citric acid and glyoxylate cycles. They are monomeric enzymes containing single iron-sulphur clusters which are interconvertible between the catalytically active $[4 \mathrm{Fe}-4 \mathrm{~S}]$ forms and the inactive $[3 \mathrm{Fe}-4 \mathrm{~S}]$ and apo-enzyme forms (Beinert et al., 1996). Crystallographic studies have shown that porcine heart mitochondrial aconitase contains four structural domains (Robbins \& Stout, 1989). Domains 1, 2 and 3 are tightly packed around the iron-sulphur cluster, which is ligated to three cysteine residues in domain 3 , and domain 4 is connected by an extended linker to domain 3 so as to

Abbreviations: IRE, iron-responsive element; IRP, iron-regulatory protein; MV, methyl viologen; NEM, $\mathrm{N}$-ethylmaleimide; UTR, untranslated region. form a deep active-site cleft between domain 4 and the rest of the protein. This is the structural archetype for all members of the aconitase protein family including the vertebrate bifunctional iron-regulatory proteins/ cytoplasmic aconitases (IRP1/c-Acn) and the monofunctional iron-regulatory proteins (IRP2). The IRPs are cytoplasmic mRNA-binding proteins that co-ordinate the post-transcriptional synthesis of several important proteins concerned with iron metabolism in higher organisms (Hentze \& Kuhn, 1996). They block the translation of some mRNAs, e.g. ferritin mRNA, by binding to iron-responsive elements (IREs) in the $5^{\prime}$ untranslated region $\left(5^{\prime} \mathrm{UTR}\right)$ of the transcript; or alternatively they enhance the translation of other mRNAs, e.g. transferrin receptor mRNA, by increasing mRNA stability as a result of binding to IREs in the $3^{\prime}$ untranslated region of the transcript (Hentze \& Kuhn, 1996; Hirling et al., 1994; Klausner \& Rouault, 
1993; Rouault \& Klausner, 1996). In the case of IRP1 there is a reciprocal iron-dependent relationship between mRNA-binding and aconitase activity such that the $[4 \mathrm{Fe}-4 \mathrm{~S}]$ protein is catalytically active whereas the apo-enzyme binds mRNA via the active-site cleft (Hentze \& Kuhn, 1996). The RNA-binding activity of IRP1 is likewise increased in response to agents such as hydrogen peroxide and nitric oxide which induce oxidative stress and inactivate the enzyme (Pantopoulos \& Hentze, 1995a, b).

In Escherichia coli, two aconitases (AcnA and AcnB) have been identified and the existence of a third aconitase $(\mathrm{AcnC})$ has been inferred from the residual activity ( $\leqslant 5 \%$ of wild-type) detected in an $a c n A B$ double mutant (Prodromou et al., 1992; Bradbury et al., 1996; Gruer et al., 1997b). Sequence comparisons show that AcnA is $53 \%$ identical to human IRP1 and $27-29 \%$ identical to mitochondrial aconitases, whereas AcnB is only $15-17 \%$ identical to AcnA, the IRPs and mitochondrial aconitases. The major IRE-binding site of IRP1 (DLVIDHSIQVD), identified by UV cross-linking (Basilion et al., 1994), is likewise conserved at nine of the eleven positions in AcnA but only at two positions in AcnB. It is also apparent that the domain organization of $A c n B$ (4-1-2-3) is cyclically permuted relative to the arrangement (1-2-3-linker-4) found in other aconitases and the IRPs (Gruer et al., 1997a). Specific roles for $A c n A$ and $A c n B$ have been identified by physiological and enzymological studies with acn mutants (Gruer et al., 1997b), regulatory studies with acn-lacZ reporter fusions, and transcript analyses (Gruer \& Guest, 1994; Cunningham et al., 1997). Thus, AcnB is the major aconitase synthesized during the exponential phase, whereas AcnA is a stationary-phase enzyme which is also specifically induced by iron and oxidative stress. The aerobic growth of an acnA mutant is unimpaired in glucose minimal medium, indicating that this lesion is fully complemented by $a c n B^{+}$, whereas the growth of an $a c n B$ mutant is severely impaired and only slightly improved by adding glutamate. Growth is virtually abolished in an $a c n A B$ double mutant, except in the presence of glutamate, where the spontaneous mutational inactivation of the citrate synthase gene $(g l t A)$ seems to eliminate the deleterious effects of citrate accumulation and leads to the proliferation of $a c n A B$ gltA triple mutants. The regulatory studies further showed that the acnA gene is expressed from independent $\sigma^{38}$ and $\sigma^{70}$ promoters, the latter being repressed by FNR and ArcA and activated (directly or indirectly) by CRP, Fur, iron, FruR and SoxRS, whereas the acnB gene is expressed from a single $\sigma^{70}$ promoter that is repressed by ArcA, FruR and Fis, and activated by CRP.

It is not known whether any bacterial aconitases have regulatory functions like the IRPs. Aconitase is needed in Bacillus subtilis for sporulation but its mode of action is unclear (Dingman et al., 1987), and in Xanthomonas campestris a gene $(r p f A)$ which regulates pathogenicity factor production has recently been shown to encode an aconitase that may serve as an iron-responsive transcription regulator (Wilson et al., 1998). The present work shows that the apo-forms of $A c n A$ and $A c n B$ of $E$. coli each bind to the 3'UTRs of acnA mRNA and $a c n B$ mRNA and enhance the synthesis of both proteins (in vitro), presumably by increasing mRNA stability. A direct correlation between enzyme inactivation, increased Acn protein synthesis and acn mRNA stability, observed with oxidatively stressed cultures, further indicates that mRNA binding by bacterial aconitases represents a novel component of the oxidative stress response. Brief accounts of these findings were communicated previously at a Gordon Research Conference (Microbial Response to Stress, 1998) and the World Congress on Iron Metabolism (BioIron'99 Abs 5).

\section{METHODS}

Bacterial strains, plasmids and basic methods. The strains of E. coli and plasmids used as enzyme sources, genes and RNA, are listed in Table 1. An acnA expression plasmid, pGS1203, analogous to pGS783, the pET21a-derived $a c n B$ expression plasmid (Bradbury et al., 1996), was constructed by first replacing the $1.6 \mathrm{~kb} K p n \mathrm{I}-\mathrm{SalI}$ fragment of pGS447 by a 369 bp PCR-amplified fragment containing the $5^{\prime}$ end of the acnA coding region flanked by KpnI and NdeI sites at one end and the acnA SalI site at the other end, to generate pGS1202. The sequence of the cloned region was confirmed and the entire $3 \cdot 2 \mathrm{~kb}$ NdeI-HindIII fragment was then transferred to pET21a to generate pGS1203.

Cultures were grown aerobically in $2 \times \mathrm{YT}$ medium at $37^{\circ} \mathrm{C}$ with ampicillin (100 $\mu \mathrm{g} \mathrm{m} \mathrm{m}^{-1}$, when required) for plasmid isolation (Promega) and aconitase production. Protein was assayed by the Bio-Rad method with bovine serum albumin (BSA) as standard: non-denaturing PAGE and SDS-PAGE were performed according to Sambrook et al. (1989). DNA was prepared and manipulated by standard procedures (Sambrook et al., 1989). Total bacterial RNA was extracted from early-stationary-phase cultures (unless otherwise specified) by the hot acid phenol method (Aiba et al., 1981). The RNA $(100 \mu \mathrm{g})$ was resuspended in $50 \mu \mathrm{l}$ buffer containing $20 \mathrm{mM}$ Tris $/ \mathrm{HCl}$ (pH 8.0), $10 \mathrm{mM} \mathrm{MgCl}_{2}, 1 \mathrm{mM}$ DTT and $10 \%$ (v/v) glycerol before adding 20 U RNase-free DNase I and incubating at $37^{\circ} \mathrm{C}$ for $30 \mathrm{~min}$ to remove traces of DNA. The RNA was then phenol-extracted and precipitated with ethanol. Western blotting was according to Gruer et al. (1997b) using enzyme-specific polyclonal antisera. Samples containing $15 \mu \mathrm{g}$ protein were fractionated by SDS-PAGE $(10 \%$ gel $)$ and electroblotted to Hybond-C (Amersham) for staining and subsequent quantitative densitometry using a Bio-Profil (Vilber Lourmat) with $1 \mathrm{D}$ and 2D analytical software.

Overproduction, purification and assay of aconitases. The enzymes were purified from shaken cultures $(2 \times 500 \mathrm{ml})$ of JRG4004 ( $a c n A)$ and JRG3099 (acnB) grown to $\mathrm{OD}_{595} 0.5$ at $37^{\circ} \mathrm{C}$ before induction with IPTG $(1 \mathrm{mM})$ for $4 \mathrm{~h}$ at $25^{\circ} \mathrm{C}$ (AcnA) or $2 \mathrm{~h}$ at $37^{\circ} \mathrm{C}(\mathrm{AcnB})$. The bacteria were resuspended in $20 \mathrm{ml}$ Tris $/ \mathrm{HCl}$ buffer $(40 \mathrm{mM}, \mathrm{pH} \mathrm{8.0)}$ for preparing ultrasonic extracts. Ammonium ferrous sulphate $(0.25 \mathrm{mM}$, final concn) and DTT $(2.5 \mathrm{mM}$, final concn) were added to the cell-free extracts to reactivate the aconitases. Extract containing $150 \mathrm{mg}$ protein in $20 \mathrm{ml}$ was loaded on a DEAE Sepharose column $(16 \times 35 \mathrm{~mm})$, washed with 5 vols Tris $/ \mathrm{HCl}$ (40 mM, pH 8.0), and eluted with a linear gradient $(300 \mathrm{ml}$, $0-0.2 \mathrm{M}$ sodium citrate in the same buffer) using an FPLC system (Pharmacia). Coloured fractions containing AcnA or AcnB were pooled and ammonium sulphate $(1.7 \mathrm{M}$, final 
Table 1. Strains of $E$. coli and plasmids

\begin{tabular}{|c|c|c|}
\hline $\begin{array}{l}\text { Strain or } \\
\text { plasmid }\end{array}$ & Relevant characteristics & Source or reference \\
\hline W3110 & Prototroph & \\
\hline DH1 & supE44 hsdR17 recA1 endA1 gyrA96 thi-1 & Sambrook et al. (1989) \\
\hline $\mathrm{DH} 5 \alpha$ & $\Delta(\operatorname{argF}-\operatorname{lac}) U 169(\phi l a c Z M 15) \operatorname{rec} A$ & Sambrook et al. (1989) \\
\hline MC4100 & $\Delta(\arg F-l a c) U 169$ rpsL & Silhavy et al. (1984) \\
\hline DJ901 & $\Delta(\operatorname{argF}-l a c) U 169$ rpsL sup $\Delta$ sox $R$ & Greenberg et al. (1990) \\
\hline BL21/ $/ \lambda \mathrm{DE} 3$ & hsdS (גcI857 ind1 Sam7 nin5 lacUV5-T7gene1) & \\
\hline JRG2387 & DH1(pGS447) & Prodromou et al. (1991) \\
\hline JRG3099 & $\mathrm{BL} 21 / \lambda \mathrm{DE} 3(\mathrm{pGS783})$ & Bradbury et al. (1996) \\
\hline JRG3171 & DH1(pGS801) & Bradbury et al. (1996) \\
\hline JRG4004 & BL21/ $\lambda$ DE3 (pGS1203) & This work \\
\hline pGS447 & $\mathrm{pUC119}, \operatorname{acn} A^{+}, \mathrm{Ap}^{\mathrm{R}}$ & Prodromou et al. (1991) \\
\hline pGS783 & $\mathrm{pET} 21 \mathrm{a}, a c n B^{+}, \mathrm{Ap}^{\mathrm{R}}$ & Bradbury et al. (1996) \\
\hline pGS801 & $\mathrm{pUC118}, a c n B^{+}, \mathrm{Ap}^{\mathrm{R}}$ & Bradbury et al. (1996) \\
\hline pGS1203 & $\mathrm{pET} 21 \mathrm{a}, \operatorname{acn} A^{+}, \mathrm{Ap}^{\mathrm{R}}$ & This work \\
\hline
\end{tabular}

concn) was added before applying to an Ether 6505 column $(16 \times 40 \mathrm{~mm})$. The column was washed with 5 vols $40 \mathrm{mM}$ Tris $/ \mathrm{HCl}(\mathrm{pH} 8.0)$ containing $1.7 \mathrm{M}$ ammonium sulphate and the Acn protein was eluted with a linear gradient $(200 \mathrm{ml}$, $1 \cdot 7-0 \mathrm{M}$ ammonium sulphate in the same buffer). Typically about $30 \mathrm{mg}$ Acn protein (>95\% pure) was recovered.

The apo-aconitases were obtained by incubating holo-enzyme solutions with a 50-fold molar excess of EDTA ( $\mathrm{pH} \mathrm{8.0)} \mathrm{and} \mathrm{a}$ 20 -fold molar excess of potassium ferricyanide for $6 \mathrm{~min}$ at $4{ }^{\circ} \mathrm{C}$ according to Kennedy \& Beinert (1988) and the protein was recovered using a small Ether $650 \mathrm{~S}$ column, as above. Aconitase activity was measured according to Kennedy et al. (1983): one unit of activity represents $1 \mu \mathrm{mol}$ cis-aconitate formed $\mathrm{min}^{-1}$. The native (as isolated) aconitases retained $6-20 \%$ of the specific activity and approximately $70 \%$ of the iron of the fully reconstituted enzymes whereas the apoproteins were completely lacking in iron and totally inactive.

Affinity chromatography and RT-PCR procedures. Apo-AcnA and apo-AcnB $(500 \mu \mathrm{g}$ protein) were coupled to $100 \mu \mathrm{l}$ of activated $\mathrm{CH}$ Sepharose 4B (Pharmacia) by incubating for $16 \mathrm{~h}$ at $4{ }^{\circ} \mathrm{C}$ in $0 \cdot 1 \mathrm{M} \mathrm{NaHCO}$ buffer pH 8.0 containing $0.5 \mathrm{M} \mathrm{NaCl}$ (final vol., $500 \mu \mathrm{l}$ ). The affinity matrices were washed exhaustively and blocked with $0 \cdot 1 \mathrm{M}$ Tris $/ \mathrm{HCl}(\mathrm{pH}$ $7 \cdot 5)$, whereafter $20 \mu \mathrm{l}$ samples were used to prepare affinity columns. Columns were equilibrated with $20 \mu \mathrm{g}$ total MC4100 RNA in $200 \mu$ l RNA-binding buffer $(10 \mathrm{mM}$ HEPES pH $7 \cdot 5$, $3 \mathrm{mM} \mathrm{MgCl}, 0 \cdot 1 \%$ Triton X-100, $40 \mathrm{mM} \mathrm{KCl}$ and $5 \%$ glycerol), as well as $1 \% \beta$-mercaptoethanol, $200 \mu \mathrm{g}$ BSA, $150 \mathrm{U}$ RNasin (Promega) and $20 \mu \mathrm{g}$ tRNA, for $30 \mathrm{~min}$ at $20{ }^{\circ} \mathrm{C}$, and then washed with $5 \mathrm{ml}$ of the RNA-binding buffer to remove unbound RNA. Bound RNA was eluted with $50 \mu \mathrm{l}$ $0.3 \mathrm{M}$ sodium acetate buffer $(\mathrm{pH} 4 \cdot 5)$ and precipitated with ethanol.

Reverse transcription was performed with all of the affinityenriched RNA sample or $2 \mu \mathrm{g}$ of total RNA in $2 \mu \mathrm{l}$, mixed with $1 \mu \mathrm{l}$ reverse primer $(40 \mu \mathrm{M}), 1 \mu \mathrm{l}$ reverse transcriptase buffer $(10 \times)$ and $2 \mu \mathrm{ldNTPs}\left(5 \mathrm{mM}\right.$ each), and heated to $70^{\circ} \mathrm{C}$ for $10 \mathrm{~min}$ before cooling slowly to room temperature. Thereafter, $0.5 \mu \mathrm{l}$ sodium pyrophosphate $(80 \mathrm{mM}), 0.5 \mu \mathrm{l}$ actinomycin D $\left(500 \mu \mathrm{g} \mathrm{ml}^{-1}\right), 1 \mu \mathrm{l}$ placental ribonuclease inhibitor (Promega), $1 \mu \mathrm{l}$ AMV reverse transcriptase (25 U; NBL) and $\mathrm{H}_{2} \mathrm{O}$ to $10 \mu \mathrm{l}$ were added and the mixtures were incubated at $37^{\circ} \mathrm{C}$ for $90 \mathrm{~min}$ before the product DNA was precipitated by adding $1 \mu \mathrm{l}$ sodium acetate $(3 \mathrm{M} ; \mathrm{pH} 4 \cdot 5)$ and $50 \mu \mathrm{l}$ ethanol. Specific segments of cDNA ( 300-600 bp copied from relevant coding regions) were then amplified by PCR with Taq DNA polymerase (Promega) over 25 cycles using appropriate forward primers and the same reverse primers, and the products were analysed by agarose gel electrophoresis $(1.5 \%)$ using a $0 \cdot 25-10 \cdot 0 \mathrm{~kb}$ GeneRuler (MBI Fermentas) for calibration.

RNA Sepharose affinity columns were prepared by crosslinking in vitro transcription products of the A5 and B5 3'UTR fragments, or $0.3 \mu \mathrm{g}$ tRNA, to $100 \mu \mathrm{l}$ activated CH Sepharose as described above. The columns were equilibrated with Acn protein $(50 \mu \mathrm{g}$ in $200 \mu \mathrm{l}$ RNA-binding buffer) for $15 \mathrm{~min}$ at $20{ }^{\circ} \mathrm{C}$ before washing $(2 \times 2 \mathrm{ml}$ RNA-binding buffer $)$, eluting with successive $2 \times 300 \mu \mathrm{l}$ aliquots of the same buffer containing increasing concentrations of $\mathrm{NaCl}(0 \cdot 1-3 \cdot 0 \mathrm{M})$, and analysing the fractions by SDS-PAGE.

Gel retardation analysis. RNA probes were first denatured by heating at $70{ }^{\circ} \mathrm{C}$ for $5 \mathrm{~min}$ and cooled rapidly. RNA-binding reactions were performed in $1 \mu \mathrm{l} 10 \times \mathrm{RNA}$-binding buffer (100 mM HEPES pH 7.5, $30 \mathrm{mM} \mathrm{MgCl}_{2}, 1 \%$ Triton X-100, $400 \mathrm{mM} \mathrm{KCl}$ and $50 \%$, glycerol), $1 \mu \mathrm{l} \beta$-mercaptoethanol $(10 \%), 0.5 \mu \mathrm{l}$ BSA $\left(10 \mathrm{mg} \mathrm{ml}^{-1}\right), 0.5 \mu \mathrm{l}$ RNasin (Promega), $0 \cdot 2 \mu \mathrm{l}$ tRNA $\left(200 \mu \mathrm{g} \mathrm{ml} \mathrm{m}^{-1}\right)$, RNA probe $(0 \cdot 1 \mathrm{ng}$ in $1 \mu \mathrm{l})$, Acn protein and $\mathrm{H}_{2} \mathrm{O}$ to $10 \mu \mathrm{l}$, incubated at $4{ }^{\circ} \mathrm{C}$ for $30 \mathrm{~min}$. The Acn protein was pre-incubated with $N$-ethylmaleimide (NEM), when present, in buffer $(7 \mu \mathrm{l})$ for $30 \mathrm{~min}$ at $4{ }^{\circ} \mathrm{C}$ before completing the reaction mixture and adding the probe. The samples were resolved in $5 \%$ non-denaturing polyacrylamide gels, which were dried and autoradiographed.

In vitro transcription. Specific RNA molecules for gel retardation analysis were obtained by in vitro transcription of PCR-amplified DNA templates into which T3 promoters had been incorporated by including a $\mathrm{T} 3$ promoter sequence at the $5^{\prime}$ end of each forward primer. The source plasmids for DNA amplification were pGS447 (acnA) and pGS801 (acnB) and the locations of the primers used to generate specific DNA templates, A1-A7 and B1-B5, are shown in Fig. 2(a). Transcription in vitro was performed with $10 \mathrm{ng}$ PCRamplified DNA in the presence of $1 \mu \mathrm{l} \mathrm{RNasin}$ (Promega), $4 \mu \mathrm{l}$ T3 transcription buffer $(5 \times$; Promega), $2 \mu$ DTT $(100 \mathrm{mM})$, $2 \mu \mathrm{l} \mathrm{UTP}(500 \mu \mathrm{M}), 2 \mu \mathrm{l}$ ATP, GTP and UTP mix (each 
$2 \cdot 5 \mathrm{mM}), 1 \mu \mathrm{l}$ BSA $\left(20 \mathrm{mg} \mathrm{m} \mathrm{m}^{-1}\right), 2 \mu \mathrm{l}\left[\alpha^{-32} \mathrm{P}\right] \mathrm{UTP}[3000 \mathrm{Ci}$ $\mathrm{mmol}^{-1}$ (111 TBq $\mathrm{mmol}^{-1}$ ); NEN], $2 \mu \mathrm{l} \mathrm{T3}$ RNA polymerase (Promega; $40 \mathrm{U}$ ) and water to $20 \mu \mathrm{l}$. After incubation at $37^{\circ} \mathrm{C}$ for $90 \mathrm{~min}, 10 \mathrm{U}$ RNase-free DNase I was added to remove the DNA templates, and labelled RNA was purified by phenol and ethanol precipitation.

In vitro transcription-translation. DNA $(1 \mu \mathrm{g})$, either uncut plasmid DNA or gel-purified PCR-amplified DNA (Expand High Fidelity PCR System, Boehringer), was mixed with $3.75 \mu \mathrm{l} \mathrm{S} 30$ extract (linear), $0 \cdot 25 \mu \mathrm{l}\left[{ }^{35} \mathrm{~S}\right]$ methionine $[1000 \mathrm{Ci}$ mmol (37 TBq $\mathrm{mmol}^{-1}$ ); ICN], $1.25 \mu \mathrm{l}$ amino acid mixture minus methionine, $5 \mu \mathrm{l} \mathrm{S30}$ premix, aconitase (where stated) and $\mathrm{H}_{2} \mathrm{O}$ to $12 \cdot 5 \mu \mathrm{l}$, before incubating at $37^{\circ} \mathrm{C}$ for $90 \mathrm{~min}$ (Promega, E. coli S30 Extract System for Linear Templates). When used, NEM was incubated with the aconitase $(30 \mathrm{~min}$ at $4{ }^{\circ} \mathrm{C}$ in $2.5 \mu \mathrm{l}$ ) before completing the reaction mixtures. Translation products were precipitated with $50 \mu \mathrm{l}$ acetone and resuspended in loading buffer for SDS-PAGE fractionation, autoradiography and quantitative analysis of ${ }^{35}$ S-labelled components (c.p.m.), which were excised from the gels and counted in vials containing $3 \mathrm{ml}$ Safefluor S (Lumac-LSC) using a Beckman LS 1801 Liquid Scintillation System.

Methyl-viologen-induced oxidative stress. The effects of methyl viologen (MV) on Acn activity and Acn protein synthesis were studied with cultures of E. coli DJ901 ( $\Delta$ soxR) grown for $2 \mathrm{~h}$ to exponential phase. Rifampicin $\left(200 \mu \mathrm{g} \mathrm{ml} \mathrm{m}^{-1}\right)$ was added followed immediately by MV and incubation for a further $1 \mathrm{~h}$ before measuring total aconitase activity (without reactivation) and immunoblotting with specific anti-Acn sera. The effects of MV on acn mRNA content and stability were studied by adding MV $(0.3 \mathrm{mM}) 10 \mathrm{~min}$ before rifampicin $\left(200 \mu \mathrm{g} \mathrm{ml}^{-1}\right)$, to cultures of W3110. Samples taken at 0, 2, 5, 10 and 20 min were chilled immediately to $4{ }^{\circ} \mathrm{C}$ in liquid $\mathrm{N}_{2}$ for RNA extraction and quantitative Northern blotting analysis. The RNA samples $(25 \mu \mathrm{g})$ were fractionated in $1 \%$ agarose formaldehyde gel, transferred to Hybond-N (Amersham), and hybridized with $\left[\alpha^{32} \mathrm{P}\right] \mathrm{dCTP}$-labelled probes according to the 'Ready to Go' labelling-kit instructions (Pharmacia). The $a c n A$ and $a c n B$ probes containing the intact $2.5 \mathrm{~kb}(a c n A)$ and $2.8 \mathrm{~kb}(a c n B)$ coding regions, were generated by PCR and the relative densities of hybridized bands were measured with an Instant Imager (Electronic Autoradiography; Packard).

\section{RESULTS}

\section{Specific RNA binding by AcnA and AcnB}

In view of the close structural relationship between AcnA and IRP1, the possibility that one or both of the E. coli aconitases might bind to specific mRNAs and modulate protein synthesis at the post-transcriptional level was investigated. Direct evidence for mRNA binding by $A c n A$ and $A c n B$ was accordingly sought using a combination of affinity chromatography and RT-PCR. Affinity columns prepared from CH Sepharose coupled to apo-AcnA and apo-AcnB were equilibrated with total bacterial RNA purified from MC4100, and washed free of unbound RNA before eluting and precipitating bound RNA. The presence of specific mRNAs in the affinity-purified material was then investigated by RT-PCR using pairs of primers designed to amplify specific segments of the coding regions of selected genes. The efficacy of the primers was established by showing that products of the predicted size were amplified when total RNA was used (Fig. 1). The experiments showed that $a c n A \mathrm{mRNA}$ and $a c n B$ mRNA bind to both types of column but not to the unliganded matrix (Fig. 1a, b). No acn mRNA was detected when reverse transcriptase was omitted from the amplification reactions or when no RNA was added to the affinity matrices at the first stage (not shown). The specificity of the interaction with the $a c n A$ and $a c n B$ transcripts was inferred from the failure to detect the highly abundant transcript of a related citric acid cycle gene $(s u c D)$ or transcripts of the iron-regulated bacterioferritin gene $(b f r)$ in the bound RNA fraction, even though these transcripts were present in the initial samples of total bacterial RNA (Fig. 1c, d). It was therefore concluded that apo-AcnA and apo-AcnB each interact with some degree of specificity to $a c n A$ and $a c n B$ mRNA. This could be mediated by one or more sequence motifs that are shared by both of the acn transcripts and presumably by other untested transcripts, but not by the $s u c D$ or $b f r$ transcripts. Attempts were made to identify other bound transcripts by making cDNA libraries of the affinitypurified RNA in pUC18. However, this was frustrated by the high proportion of clones (all of 20 tested) that contained $16 \mathrm{~S}$ rRNA or $23 \mathrm{~S}$ rRNA sequences, which are presumably bound non-specifically. No attempts were made to compare the RNA-binding activities of affinity columns made with apo-protein versus native protein because the latter invariably contain some apo-protein which would react positively.

\section{Location of Acn-binding sites in acn transcripts}

Local homology searches in the regions flanking and overlapping the $a c n A$ and $a c n B$ genes failed to reveal conserved sequences or secondary structural features like IREs that might serve as Acn-binding sites. The presence and location of such sites was investigated by gel retardation analysis using both aconitases and overlapping segments of the $5^{\prime}$ and $3^{\prime}$ UTRs of both acn transcripts derived by transcription in vitro from two plasmids, pGS447 (acnA) and pGS801 (acnB), as shown in Fig. 2(a). Specific retardation by apo-AcnA and apoAcnB was only observed with two RNA fragments, A5 and B5, representing the $3^{\prime} \mathrm{UTR}$ s of the $\operatorname{acn} A$ and $B$ transcripts (Fig. 2b). No specific retardation was observed with any of the $5^{\prime}$ UTR fragments shown in Fig. 2(a). Likewise, subsegments of the 3'UTR fragments (A4, A6, B3 and B4) were not retarded, suggesting that more than one binding site is required or that long molecules are essential for AcnA and AcnB binding. The retardation patterns also indicated that more than one protein molecule can be bound (Fig. 2b).

Apo-AcnA had a lower affinity $\left(K_{\mathrm{D}} \approx 8 \mu \mathrm{M}\right)$ for both A5 and B5 compared to Apo-AcnB $\left(K_{\mathrm{D}} \approx 1.3 \mu \mathrm{M}\right)$, where $K_{\mathrm{D}}$ denotes the protein concentration giving halfmaximal initial retardation. Although relatively low, the binding affinities are physiologically significant when related to the intracellular concentrations of aconitase deduced from specific activity measurements and Western blotting analysis : $1-6 \mu \mathrm{M}$ for AcnA and $2-12 \mu \mathrm{M}$ for $A c n B$, at different stages of the growth cycle (Gruer et 
(a) $\operatorname{acn} A$

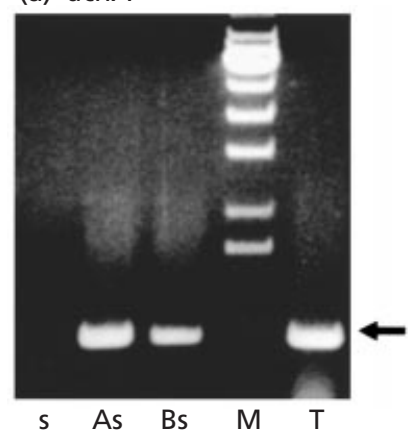

(b) $a c n B$

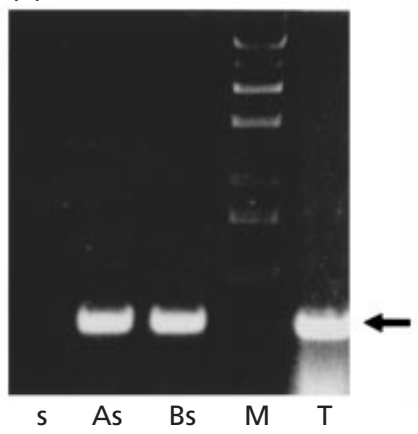

(c) $\operatorname{sucD}$

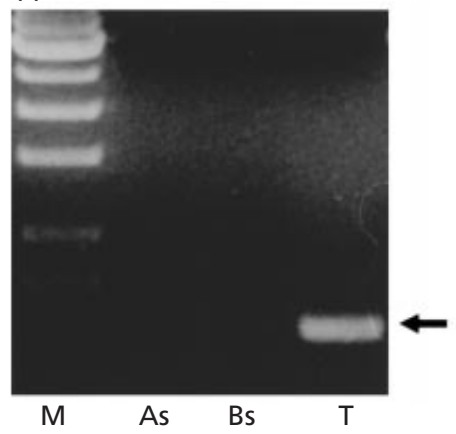

(d) $b f r$

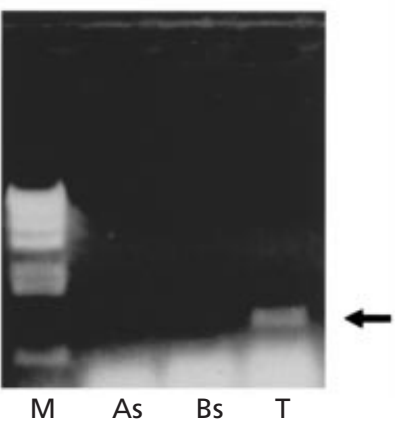

Fig. 1. RNA binding to immobilized $A c n A$ and $A c n B$ apo-proteins. The presence of specific transcripts in affinity-purified RNA was detected after RT-PCR amplification with gene-specific primers by agarose gel electrophoresis. The samples of bound RNA were eluted from unliganded Sepharose (s), AcnA-Sepharose (As) and AcnB-Sepharose (Bs). Total unfractionated RNA ( $T$ ) was used as a control. The predicted sizes of the products (shown below) were confirmed by comparison with standard markers (M). The primers were designed to amplify specific segments of the coding regions of the following genes: (a) acnA (354 bp); (b) acnB (370 bp); (c) sucD (518 bp); (d) bfr (431 bp).

(a)

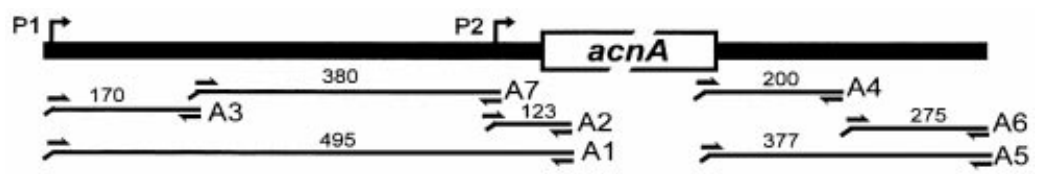

$100 \mathrm{bp}$

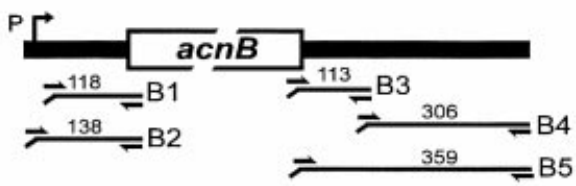

(b)

(i)

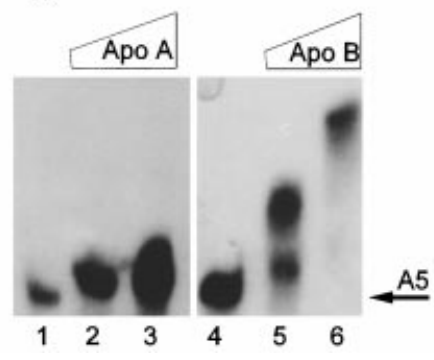

(ii)

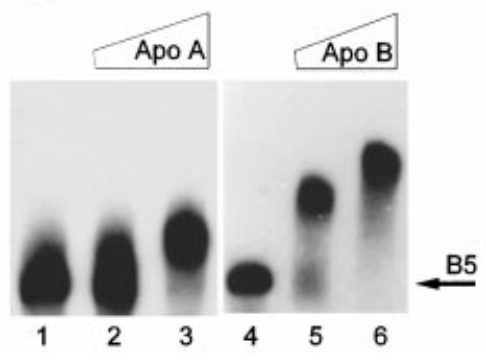

Fig. 2. Location of the Acn-binding regions of acnA mRNA and $a c n B$ mRNA by gelretardation analysis. (a) Diagram showing segments of the $5^{\prime}$ and $3^{\prime}$ UTRs of the acnA and $a c n B$ transcripts (A1-A6 and B1-B5) synthesized by transcription (in vitro) with T3 RNA polymerase using templates that were PCR-amplified from acnA and $a c n B$ plasmids using different pairs of oligonucleotide primers (converging arrows). The angled $5^{\prime}$ extremities denote the T3 promoter sequences incorporated by the forward primers, and the total length of each amplified molecule (bp) is indicated. (b) Gel retardation by apo-Acn proteins of radiolabelled RNA fragments (i) A5 and (ii) B5: lanes 1 and 4, no protein; lane 2, $12 \mu \mathrm{g}$ apo-AcnA; lane $3,24 \mu \mathrm{g}$ apo-AcnA; lane 5 , $3 \mu \mathrm{g}$ apo-AcnB; lane $6,5 \mu \mathrm{g}$ apo-AcnB. No other fragments or subfragments were specifically retarded by AcnA or AcnB. al., 1997b). The shifts were correspondingly smaller for AcnA than those induced by AcnB (Fig. 2b). This could reflect inherently different Acn-binding affinities based on binding-site recognition. Alternatively, the presence of 124 additional amino acid residues in domain 4 of AcnB and correspondingly fewer in domains 1-3 compared to AcnA (Gruer et al., 1997a) might have a greater effect on the mobility of the apo-AcnB-RNA complex, especially if RNA is bound in the active-site cleft.

In order to ensure that the natural acn transcripts extend across the regions of Acn binding, RT-PCR was used with total E. coli RNA to provide evidence for transcription of the corresponding 3'UTRs. Two series of reverse primers designed to generate and amplify cDNAs from 169, 269 and 336 bp downstream of the acnA stop codon, and 81, 199, 308, 482 and 528 bp downstream of the $a c n B$ stop codon, were paired with forward primers hybridizing within the respective coding regions. Amplified products were obtained in every case except in the controls lacking reverse transcriptase. Thus it was concluded that even though the $3^{\prime}$ transcription termini were not defined, they are located downstream of the longest 3'UTR segments (A5 and B5) studied here.

\section{Effects of the AcnA and AcnB proteins on acn gene expression in vitro}

The regulatory effects of IRPs have been observed in transcription-translation systems in vitro (Kim et al., 1996; Gray et al., 1993). Analogous studies with an E. 


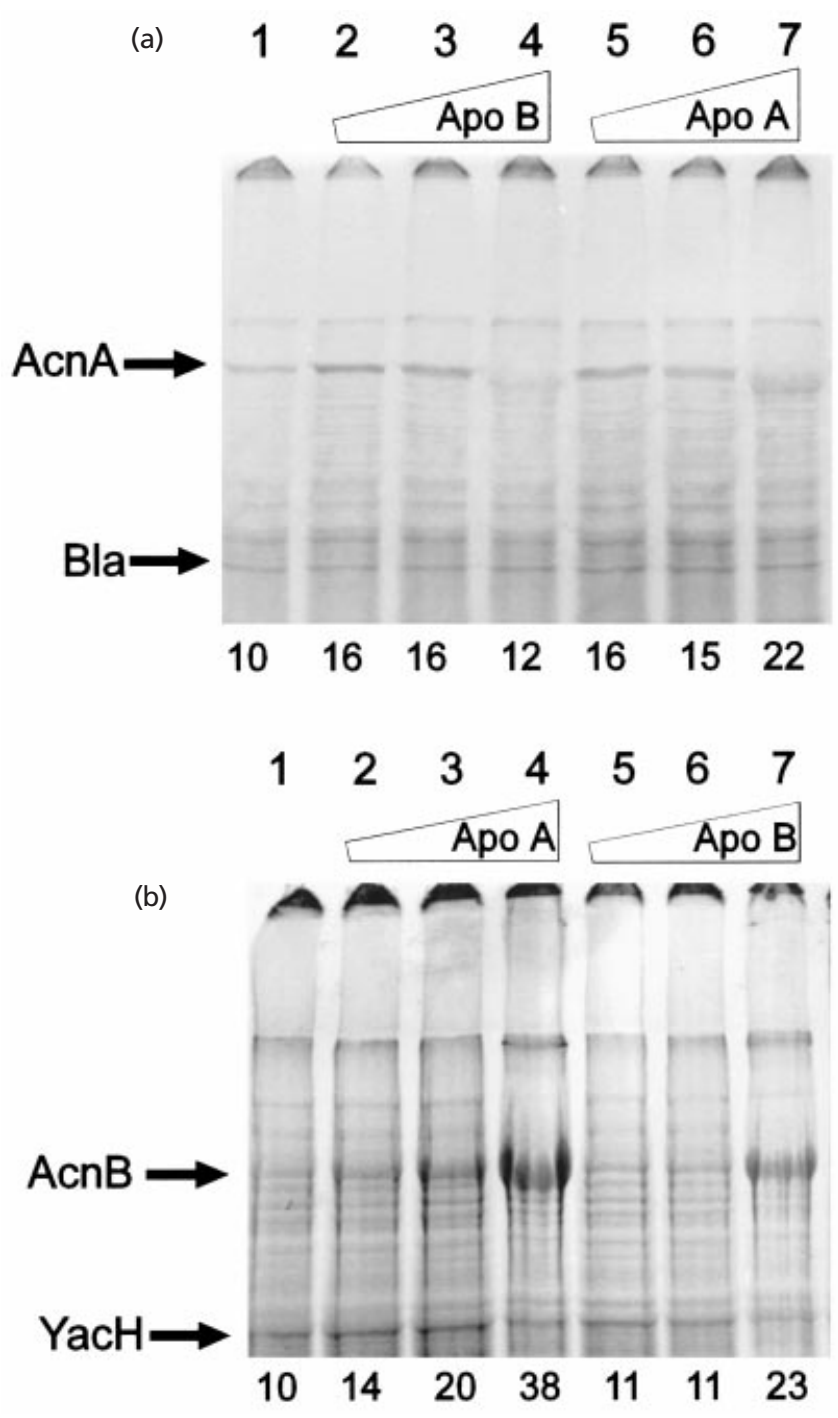

Fig. 3. Effects of apo-Acn proteins on the in vitro transcription-translation of acn genes. Newly synthesized ${ }^{35} \mathrm{~S}$ labelled products were fractionated by SDS-PAGE and analysed autoradiographically and by scintillation counting of excised bands. The relative extents of Acn labelling are indicated below each track, where $10=90$ (a) or 70 (b) c.p.m. per band above background ( $\sim 20$ for comparable gel slices). (a) Products expressed from the acnA plasmid (pGS447) in the presence of apo-Acn proteins $\left(\mu \mathrm{g} \mathrm{ml}^{-1}\right)$ : no Acn (lane 1); apo-AcnB, 20 (lane 2), 200 (lane 3) and 2000 (lane 4); apo-AcnA, 20 (lane 5), 200 (lane 6) and 2000 (lane 7). (b) Products expressed from the $a c n B$ plasmid (pGS801) in the presence of apo-Acn proteins $\left(\mu \mathrm{g} \mathrm{ml}^{-1}\right)$ : no Acn (lane 1); apo-AcnA, 24 (lane 2), 240 (lane 3) and 2400 (lane 4); apo-AcnB, 16 (lane 5), 160 (lane 6) and 1600 (lane 7).

coli transcription-translation system showed that the apo-forms of $A c n A$ and $A c n B$ increase the de novo synthesis of both aconitases by up to fourfold, based on plasmid-directed incorporation of ${ }^{35} \mathrm{~S}$ into AcnA and AcnB (Fig. 3). The stimulatory effects were apparent at apo-Acn concentrations as low as $0 \cdot 2 \mu \mathrm{M}(20 \mu \mathrm{g}$ protein $\mathrm{ml}^{-1}$ ) except in one case where higher concentrations $\left(\geqslant 2 \cdot 4 \mu \mathrm{M} ; 240 \mu \mathrm{g}\right.$ protein $\left.\mathrm{ml}^{-1}\right)$ of apo-AcnB were needed to stimulate $a c n B$ expression. In the same experiments, expression of the plasmid-encoded bla and yacH genes was unaffected by the aconitases (Fig. 3). No incorporation in the Acn region was observed with vector controls, nor was any enhancement observed with comparable concentrations of bovine serum albumin. It was therefore concluded that the Acn apoproteins specifically enhance expression of the acn genes, possibly at the translational level by acn transcript stabilization (via 3'UTR binding), as proposed for IRP1 and transferrin receptor mRNA.

\section{Role of the $3^{\prime}$ UTR in translational enhancement and mRNA binding}

In order to confirm that the 3'UTRs of the acn mRNAs are needed for Acn-mediated translational enhancement and to locate potential Acn-binding sites, two series of PCR-amplified fragments containing acn genes that terminate at different $3^{\prime}$ positions were used as linear templates in in vitro transcription-translation reactions (Fig. 4). With acnA a 3'UTR of between 71 and $169 \mathrm{bp}$ was needed for translational enhancement by the apoAcn proteins; with $a c n B$ an 80 bp 3'UTR was sufficient to detect enhancement at high protein concentrations but better enhancement was observed with a $297 \mathrm{bp}$ 3'UTR. Further support for the existence of specific interactions between the Acn apo-proteins and acn 3'UTRs was obtained using affinity columns prepared by cross-linking the $3^{\prime} \mathrm{UTRs}$ (A5 and B5 in Fig. 2) and tRNA to CH Sepharose (see Methods). Apo-AcnA and apo-AcnB were bound to the A5 and B5 Sepharose matrices in RNA-binding buffer and released by adding salt to the eluting buffer but neither protein was bound to tRNA Sepharose (data not shown).

\section{Effects of treating the Acn proteins with NEM}

The RNA-binding activity of IRP1 is extremely sensitive to alkylation of the highly conserved Cys-357 residue with NEM (Hirling et al., 1994). In contrast, the RNAbinding activities of both Acn apo-proteins were impaired only by treatment with NEM at low concentrations $(0.01-0.06 \mathrm{mM})$ and were unaffected or even augmented with higher NEM concentrations $(0 \cdot 6-$ $1.0 \mathrm{mM}$ ) that would completely abolish IRP1 activity. Nevertheless, these observations served to demonstrate that there is a direct correlation between the mRNAbinding and in vitro translation-enhancing activities of the Acn proteins because $a c n A$ and $a c n B$ expression was impaired with apo-proteins treated with 0.01 and $0.1 \mathrm{mM}$ NEM but augmented by treatment with $1.0 \mathrm{mM}$ NEM (data not shown).

\section{Effects of stress factors on Acn enzyme activity, Acn synthesis and acn mRNA stability, in vivo}

Oxidative stress factors abolish the catalytic activity with the concomitant acquisition of the mRNA-binding and stabilizing activities of IRP1 (Pantopoulos \& 
(a)
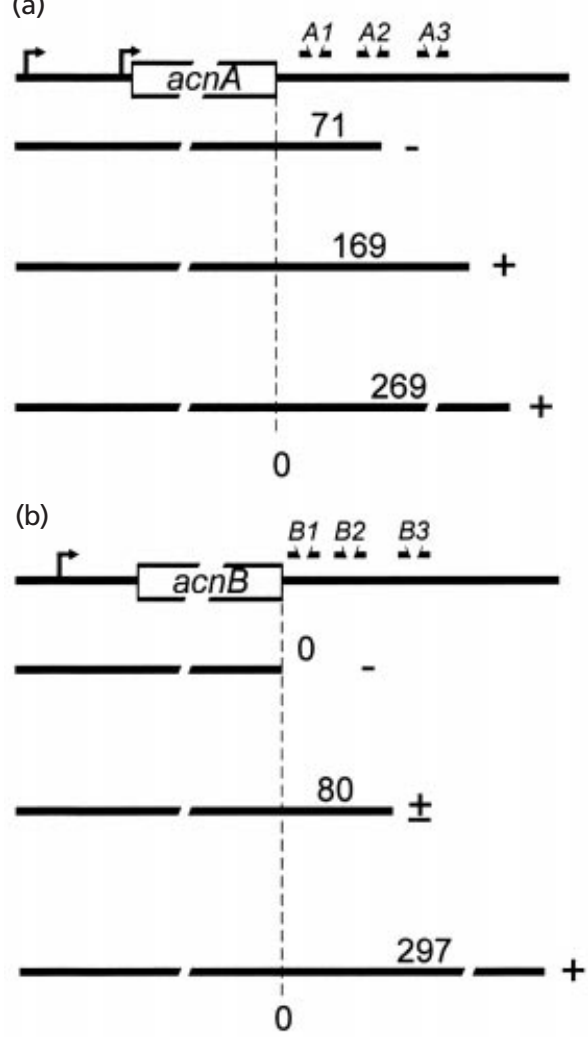
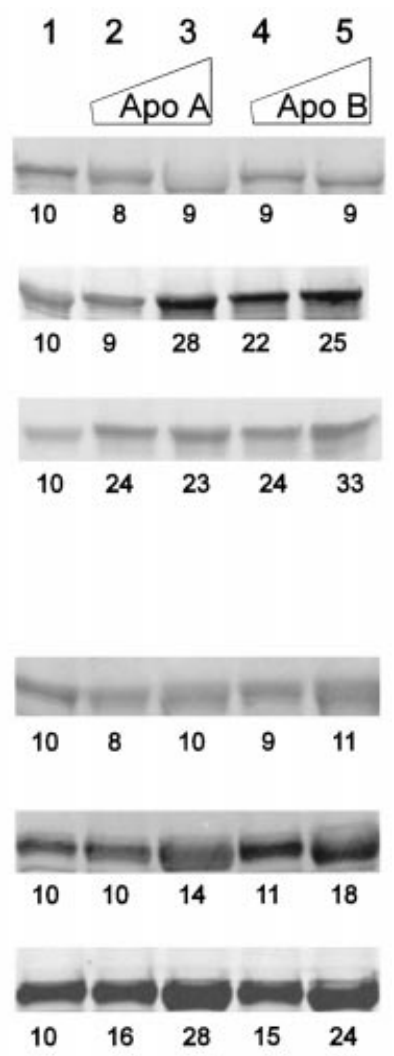

Fig. 4. Stimulation of in vitro transcription-translation by Acn apoproteins using acn genes with nested $3^{\prime}$ UTR deletions as templates. PCR amplification was used to generate acn genes that extend to different positions beyond the stop codons (distance from stop codon indicated in $\mathrm{bp}$; total length of template $\sim 3.5 \mathrm{~kb}$ ). These served as linear acnA (a) or $a c n B$ (b) templates in in vitro transcriptiontranslation reactions with different Acn proteins $\left(\mu \mathrm{g}\right.$ protein $\mathrm{ml}^{-1}$ ): no Acn (lane 1); apo-AcnA, 120 (lane 2) and 1200 (lane 3); apo-AcnB, 120 (lane 4) and 1200 (lane 5). The relative extents of Acn labelling are shown below each autoradiograph, where 10 represents $70-150$ c.p.m. per band above background (25 c.p.m.). The converging arrows (A1-3 and B1-3) denote potential stem-loops in the transcripts.
Hentze, 1995a, b; Constable et al., 1992). The conversion of active bacterial aconitases to the inactive [3Fe-4S] or apo-enzyme forms could likewise provide a comparable stress-responsive switch for stabilizing acn and other relevant transcripts in vivo, especially as the aconitase activity of E. coli is known to be sensitive to oxidative stress (Gardner \& Fridovich, 1992; Gardner et al., 1997). Accordingly, the effect of MV-induced oxidative stress on aconitase activity and Acn protein synthesis was investigated in growing cultures of E. coli. Strain DJ901 $(\Delta s o x R)$ was chosen because it allowed translation to be studied during oxidative stress without interference from SoxRS-dependent activation of $a c n A$ transcription (Gruer \& Guest, 1994; Cunningham et al., 1997). In a typical experiment the total aconitase activity decreased by $60 \%$ whilst the $A c n A$ and $A c n B$ proteins increased three- to fourfold in response to added MV (Fig. 5). Similar reciprocal effects were observed with $\mathrm{H}_{2} \mathrm{O}_{2}(0.5 \mathrm{mM})$ and manganous ions $(50 \mu \mathrm{M})$. These findings are therefore consistent with the view that inactivated aconitases enhance the synthesis of Acn proteins in vivo, presumably by stabilizing the corresponding mRNAs.

Direct evidence that oxidative stress stabilizes the $a c n A$ and $a c n B$ transcripts was obtained by measuring their half-lives in cultures of W3110 that had been treated with and without MV for 10 min before adding rifampicin to block transcription initiation (see Methods). After the anticipated MV-induced increase in $\operatorname{acn} A$

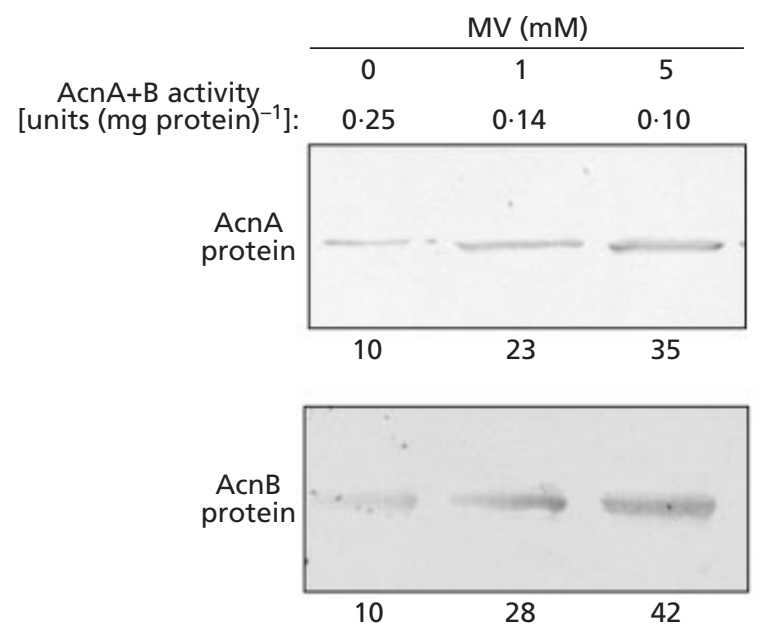

Fig. 5. Effects of MV-induced oxidative stress on total aconitase activity and Acn protein synthesis (in vivo). Cultures of $E$. coli DJ901 ( $\Delta$ soxR) were grown for $2 \mathrm{~h}$ before adding rifampicin $\left(200 \mu \mathrm{g} \mathrm{ml} \mathrm{m}^{-1}\right)$ to block transcription initiation, followed immediately by MV. Cell-free extracts were prepared after $1 \mathrm{~h}$ for assaying total aconitase specific activity and for immunoblotting to determine the relative amounts of the individual Acn proteins (shown below each panel).

transcription (Cunningham et al., 1997), the half-life of acnA mRNA increased from $4 \mathrm{~min}$ to $17 \mathrm{~min}$ and that of $a c n B \mathrm{mRNA}$ increased from $7 \mathrm{~min}$ to $15 \mathrm{~min}$, relative to 

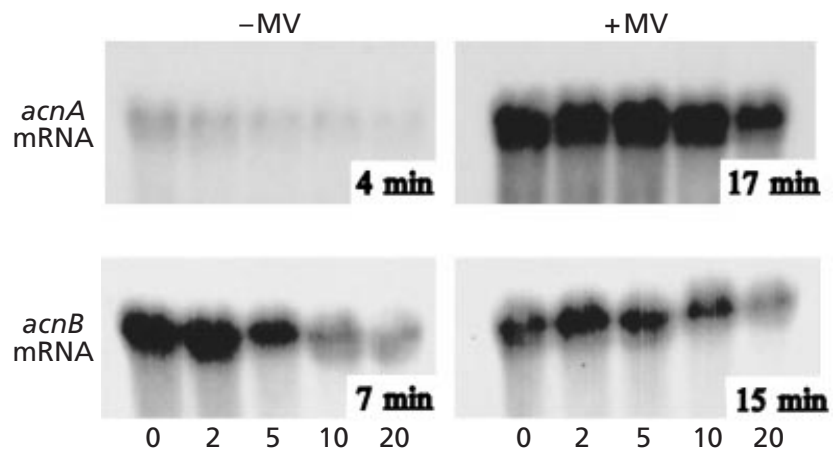

Fig. 6. Effects of MV-induced oxidative stress on acn mRNA stability. The acn transcripts in cultures of E. coli W3110 treated with and without MV for 10 min were quantified by Northern blotting at different times (0-20 min) after adding rifampicin (see Methods), in order to deduce the corresponding transcript half-lives (shown in each panel).

untreated controls (Fig. 6). The results clearly show that oxidative stress increases acn transcript stability and hence transcript concentration in the absence of de novo transcription. They also confirm that oxidative-stressmediated translational enhancement, presumably by apo-Acns, occurs in vivo as well as in vitro.

\section{Direct in vitro evidence for a regulatory switch}

Evidence for an iron-sulphur-cluster-dependent and oxidative-stress-responding regulatory switch was obtained by comparing the RNA-binding activities of the native (as isolated) and apo forms of the bacterial aconitases (Fig. 7). Compared to apo-AcnA $\left(K_{\mathrm{D}} \approx 8 \mu \mathrm{M}\right)$, native AcnA had no detectable effect on the mobility of B5 (the 3'UTR fragment of $a c n B$ ) at the highest concentration tested, indicating that the affinity of the native enzyme $\left(K_{\mathrm{D}}>24 \mu \mathrm{M}\right)$ is at least threefold lower than that of the native enzyme. Tests at even higher concentrations were precluded by the concen- tration of the purified enzyme. The RNA-binding affinity deduced for native AcnB $\left(K_{\mathrm{D}} \approx 4 \cdot 0 \mu \mathrm{M}\right)$ was likewise approximately threefold lower than that observed for apo-AcnB $\left(K_{\mathrm{D}} \approx 1.3 \mu \mathrm{M}\right)$. Furthermore, in view of the extreme oxidative instability of native $A \mathrm{cnB}$ protein, the $K_{\mathrm{D}}$ of the pure holo-protein is likely to be considerably greater than $4 \cdot 0 \mu \mathrm{M}$. These observations suggest that the RNA-binding activity of the bacterial aconitases is, like that of IRP1/c-Acn, modulated by the presence or absence of an iron-sulphur cluster such that there is a reciprocal relationship between the enzyme and RNAbinding activity.

\section{DISCUSSION}

The close structural relationship between E. coli AcnA and the bifunctional IRP1s of higher organisms prompted a series of in vitro and in vivo experiments which revealed the existence of a post-transcriptional mechanism for positive autoregulation of AcnA and $A c n B$ synthesis by their apo-proteins. It was further inferred from the effects of MV that conversion of the active holo-enzyme into a site-specific mRNA-binding apo-protein by oxidative [4Fe-4S]-cluster degradation provides a stress-responsive regulatory switch, as in the case of IRP1. In bacteria, where stress responses are primarily controlled at the transcriptional level by specific regulators like Fur, SoxRS, OxyR and FNR, the Acn-mediated system offers a rapidly responding mechanism for modulating translation that may be of much greater general significance than simply controlling Acn synthesis. However, there are significant differences between the IRP1 and bacterial Acn systems, particularly with respect to mRNA-binding affinity, bindingsite specificity, and potential physiological functions.

Early attempts to detect AcnA binding to mammalian IREs by gel retardation were unsuccessful (R. D. Klausner \& J. R. Guest, unpublished) and the same was found with MICP, the AcnA of Legionella pneumophila (Mengaud \& Horwitz, 1993). Three IRE-like sequences of unknown significance have been found in E. coli (a)

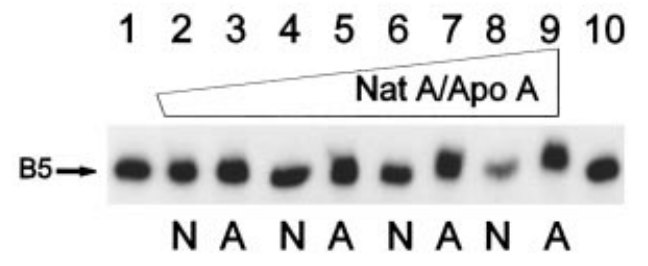

(b)

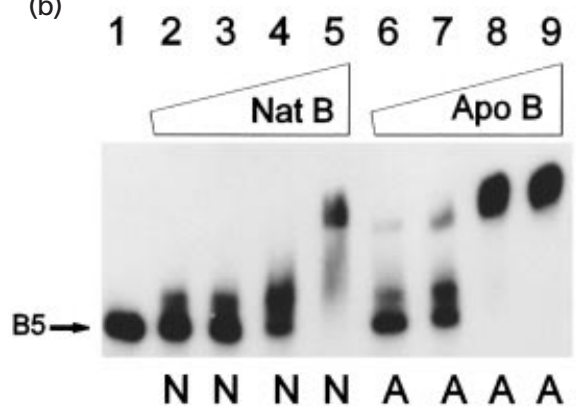

Fig. 7. Comparison of the RNA-binding activities of native and apo-aconitases: gel retardation of RNA fragment B5 transcribed from the $3^{\prime}$ UTR of the $a c n B$ gene (Fig. 2) with native (as isolated) aconitase (N) and aconitase apo-protein (A). (a) Native AcnA and apo-AcnA in alternate lanes: 1 and 10, no protein; 2 and $3,3 \mu \mathrm{g} ; 4$ and $5,6 \mu \mathrm{g} ; 6$ and $7,12 \mu \mathrm{g} ; 8$ and 9, $24 \mu \mathrm{g}$. (b) Native AcnB and apo AcnB in lanes: 1, no protein; 2 and $6,1 \mu \mathrm{g} ; 3$ and $7,2 \mu \mathrm{g} ; 4$ and $8,5 \mu \mathrm{g} ; 5$ and 9 , $10 \mu \mathrm{g}$. 


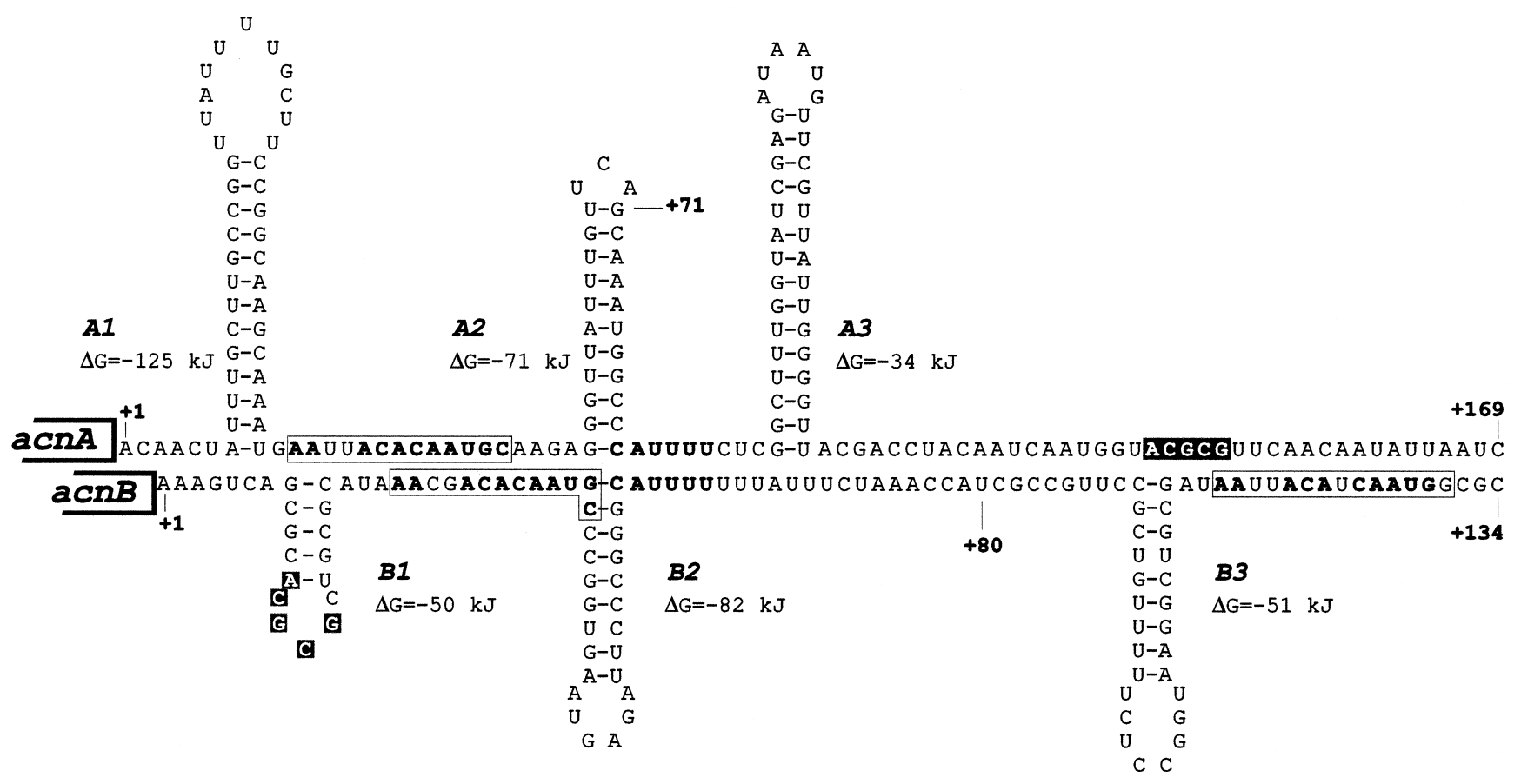

Fig. 8. Potential secondary structures of the $\operatorname{acn} A$ and $a c n B$ 3'UTRs. Putative stem-loops, denoted $\boldsymbol{A} \mathbf{1}-\mathbf{3}$ and $\boldsymbol{B} \mathbf{1}-\mathbf{3}$ as in Fig. 5, are shown with the corresponding free energies. The sequences are numbered from the bases that immediately follow the stop codons; identical or related motifs shared by both sequences are shown in bold-face, boxed or highlighted.

(Dandekar et al., 1998): one is in the $f r d B$ coding region; another is in a large multi-component stem-loop and coding region located upstream of the $f e p B$ gene; and the third is in the $5^{\prime}$ UTR of the hemA gene. The transcription-translation activity of a hemA-lacZ fusion of uncertain origin (kindly provided by R. P. Gunsalus) was unaffected by inactivating the $\operatorname{acn} A$ and $a c n B$ genes (M. A. Quail \& J. R. Guest, unpublished).

The binding affinities of apo-AcnA and apo-AcnB for the acn $3^{\prime}$ UTRs ( $K_{\mathrm{D}} \approx 8.0$ and $1.3 \mu \mathrm{M}$, respectively) are much lower than have been reported for IRP1 and IRE $\left(K_{\mathrm{D}}=5-50 \mathrm{pM}\right.$; Butt et al., 1996). Nevertheless, relative to the intracellular concentrations of AcnA and AcnB (6 and $12 \mu \mathrm{M}$ maximum, respectively), the apo-protein binding affinities are entirely compatible with the operation of two sensitive physiologically poised switches. Higher affinities might indeed be deleterious to the growth of E. coli. In view of its great instability, AcnB could provide a particularly sensitive mechanism for stress-induced apo-enzyme formation and mRNA binding/stabilization. It is possible that the observed mRNA-binding affinities are underestimated because the formation of stem-loops that might be needed for optimal apo-Acn binding could have been limited by the use of denatured and rapidly cooled RNA in the gel retardation experiments. It is also relevant that longer 3'UTRs are needed for retardation than for detecting translational enhancement in vitro. Thus, the shorter subfragments, A4 and B3, were not retarded (Fig. 2) even though they contain sufficient of the $3^{\prime} \mathrm{UTR}$ to enhance AcnA and AcnB synthesis from DNA-derived transcripts in transcription-translation tests (Fig. 4). This could mean that the 3'UTRs contain several apo-Acn-binding sites, not all of which are located in the minimal fragments, or that secondary structural elements form more readily in longer RNA molecules.

Attempts to identify potential binding sites for the Acn apo-protein by comparing the sequences and secondary structural features of the two acn 3'UTRs revealed two paired motifs, AA-ACACAAUGC and CAUUUU, that flank putative stem-loops $\boldsymbol{A} 2$ and $B 2$ in each $3^{\prime}$ UTR (Fig. 8). Their locations correlate precisely with the minimal requirements for detecting translational enhancement, $169>A>71$ and $80>B>0 \mathrm{bp}$, for the respective $a c n A$ and $a c n B 3^{\prime}$ UTRs (Fig. 4). There is also a sequence related to the first of these motifs downstream of B3 (Fig. 8), which might contribute to a second binding site and simultaneously explain why a longer 3'UTR (279 bp) improves translational enhancement with $a c n B$. If significant, these motifs should be regarded as common features of potentially different AcnA- and AcnB-binding sites because there is no evidence that the two apo-proteins bind to identical sites even though they exhibit overlapping regulatory activities. These sites are clearly different from IREs, where sequence conservation is largely confined to the loops of the stem-loops recognized by IRPs. Searching the E. coli genome for pairs of motifs analogous to those flanking the $A 2$ and $B 2$ stem-loops, but with variable hyphenation, revealed no identities. Sequences differing at only one position 
exist but there were no preferred locations or functional relationships among the corresponding genes.

The view that the regulatory switch is mediated by the conversion of holo-enzyme to apo-enzyme is supported by the more than threefold and threefold higher affinities of the apo-proteins relative to the native proteins for both acn 3'UTRs (Fig. 7). The real activation thresholds are likely to be considerably higher than threefold because the native (as isolated) enzymes invariably contain some apo-protein and both enzymes are very susceptible to aerobic inactivation and iron-sulphur cluster degradation. This is particularly so for $A c n B$, which is inactivated (and reactivated) seven (and ten) times faster than AcnA (A. Bradbury \& J. R. Guest, unpublished observations). It is known that transcript processing and degradation plays an important part in regulating gene expression in E. coli and that mutations affecting various ribonucleases lower the rate of mRNA decay (Arraiano et al., 1997; Kushner, 1996). The apoaconitases could thus regulate Acn synthesis by binding to the 3'UTRs of the acn mRNAs to block transcript processing and 3'exoribonuclease progression. Indeed, the half-lives of both $a c n$ mRNAs were here shown to increase two- to threefold during MV-induced oxidative stress, which is known to convert aconitase to its apoform. It is also conceivable that, like IRP, apo-Acn could block or impair translation by binding to the $5^{\prime}$ UTRs of specific mRNAs. In this context it interesting to note that oxidative stress lowers the half-life of soxS mRNA from $3 \cdot 2$ to $1 \cdot 2 \mathrm{~min}$ (Ding \& Demple, 1997) because this could be mediated by apo-Acn formation.

The overlapping (cross-reacting) feature of the proposed AcnA/B autoregulatory system probably ensures that despite variations in relative amounts of the two $a c n$ transcripts (and their products) in different growth phases, Acn synthesis will increase in response to oxidative stress. However, in view of the sixfold higher affinity of apo-AcnB for acn 3'UTR fragments relative to apo-AcnA, it is envisaged that $A c n B$ will play the major role in mounting a particularly sensitive response to oxidative stress in growing cultures by enhancing the synthesis of the stabler AcnA (as well as AcnB) for survival and recovery purposes. The proposed autoregulatory mechanisms also provide a very plausible explanation for previous observations that AcnA and AcnB amplification from pUC-derived plasmids greatly exceeds the amounts expected from copy number alone (i.e. because accumulating apo-Acn stabilizes the acn transcripts).

The present work has revealed a hitherto undetected mechanism for modulating bacterial gene expression at the translational level based on the redox-sensitivity of the aconitases. It offers a rapid initial response to oxidative stress that is activated before the longer-term SoxRS and OxyR transcriptional regulatory mechanisms take effect (Hidalgo \& Demple, 1996). It is switched by the interconversion of catalytic and RNAbinding forms of aconitase just like IRP1-mediated posttranscriptional regulation. Indeed, it could be speculated that RNA binding is an inherent property of the aconitases leading to the evolution of the high-affinity IRP1 system of higher organisms, where regulating gene expression from specific relatively stable transcripts is more important than in bacteria. It is also interesting that an iron-sulphur cluster serves as the sensory cofactor as in the SoxR- and FNR-mediated switches. The Acn system has so far been shown to autoregulate aconitase synthesis but it could perform a more general role in mounting the oxidative stress response, and possibly in regulating host-pathogen interactions and bacterial differentiation, where aconitases have been implicated. Future work will be aimed at characterizing the Acn regulatory system and the effects of stress factors (using a semi-synthetic reporter gene), defining the moleular basis of the Acn-mRNA interactions, and identifying other Acn-regulated genes.

\section{ACKNOWLEDGEMENTS}

We thank Simon Andrews and Louise Cunningham for supplying $b f r$ - and sucD-specific primers, and Jeff Green, Colin Scott and Guanghui Wu for helpful advice and discussions. The work was funded by a project grant from the Wellcome Trust (J.R.G.).

\section{REFERENCES}

Aiba, H., Adhya, S. \& Decrombrugghe, B. (1981). Evidence for two functional gal promoters in intact Escherichia coli cells. J Biol Chem 256, 1905-1910.

Arraiano, C. M., Cruz, A. A. \& Kushner, S. R. (1997). Analysis of the in vivo decay of the Escherichia coli dicistronic pyrF-orfF transcript: evidence for multiple degradation pathways. $J \mathrm{Mol}$ Biol 268, 261-272.

Basilion, J. P., Rouault, T. A., Massinople, C. M., Klausner, R. D. \& Burgess, W. H. (1994). The iron-responsive element-binding protein: localization of the RNA-binding site to the aconitase active-site cleft. Proc Natl Acad Sci USA 91, 574-578.

Beinert, H., Kennedy, M. C. \& Stout, C. D. (1996). Aconitase as iron-sulfur protein, enzyme and iron-regulatory protein. Chem Rev 96, 2335-2373.

Bradbury, A. J., Gruer, M. J., Rudd, K. E. \& Guest, J. R. (1996). The second aconitase (AcnB) of Escherichia coli. Microbiology 142, 389-400.

Butt, J., Kim, H.-Y., Basilion, J. P., Cohen, S., Iwai, K., Philpott, C. C., Altschul, S., Klausner, R. D. \& Rouault, T. A. (1996). Differences in the RNA binding sites of iron regulatory proteins and potential target diversity. Proc Natl Acad Sci USA 93, 4345-4349.

Constable, A., Quick, S., Gray, N. K. \& Hentze, M. W. (1992). Modulation of the RNA-binding activity of a regulatory protein by iron in vitro: switching between enzymatic and genetic function? Proc Natl Acad Sci USA 89, 4554-4558.

Cunningham, L., Gruer, M. J. \& Guest, J. R. (1997). Transcriptional regulation of the aconitase genes $(a c n A$ and $a c n B)$ of Escherichia coli. Microbiology 143, 3795-3805.

Dandekar, T., Beyer, K., Bork. P. \& 7 other authors (1998). Systematic genomic screening and analysis of mRNA in untranslated regions and mRNA precursors: combining experimental and computational approaches. Bioinformatics 14, 271-278.

Ding, H. \& Demple, B. (1997). In vivo kinetics of a redox-regulated transcriptional switch. Proc Natl Acad Sci USA 94, 8445-8449. 
Dingman, D. W., Rosencrantz, M. S. \& Sonenshein, A. L. (1987). Relationship between aconitase gene expression and sporulation in Bacillus subtilis. J Bacteriol 169, 3068-3075.

Gardner, P. R. \& Fridovich, I. (1992). Inactivation-reactivation of aconitase in Escherichia coli: a sensitive measure of superoxide radical. J Biol Chem 267, 8757-8763.

Gardner, P. R., Costantino, G., Szabo, C. \& Salzman, A. L. (1997). Nitric oxide sensitivity of the aconitases. J Biol Chem 272, 25071-25076.

Gray, N. K., Quick, S., Goossen, B., Constable, A., Hirling, H., Kuhn, L. C. \& Hentze, M. W. (1993). Recombinant iron-regulatory factor functions as an iron-responsive-element-binding protein, a translational repressor and an aconitase: a functional assay for translational repression and direct demonstration of the iron switch. Eur J Biochem 218, 657-667.

Greenberg, J. T., Monach, P., Chou, J. H., Josephy, D. \& Demple, B. (1990). Positive control of a global antioxidant defense regulon activated by superoxide generating agents in Escherichia coli. Proc Natl Acad Sci USA 87, 6181-6185.

Gruer, M. J. \& Guest, J. R. (1994). Two genetically-distinct and differentially-regulated aconitases (AcnA and AcnB) in Escherichia coli. Microbiology 140, 2531-2541.

Gruer, M. J., Artymiuk, P. J. \& Guest, J. R. (1997a). The aconitase family: three structural variations on a common theme. Trends Biochem Sci 22, 3-6.

Gruer, M. J., Bradbury, A. J. \& Guest, J. R. (1997b). Construction and properties of aconitase mutants of Escherichia coli. Microbiology 143, 1837-1846.

Hentze, M. W. \& Kuhn, L. C. (1996). Molecular control of vertebrate iron metabolism: mRNA-based regulatory circuits operated by iron, nitric oxide, and oxidative stress. Proc Natl Acad Sci USA 93, 8175-8182.

Hidalgo, E. \& Demple, B. (1996). Adaptive resposes to oxidative stress: the soxRS and oxyR regulons. In Regulation of Gene Expression in Escherichia coli, pp. 435-452. Edited by E. C. C. Lin \& S. A. Lynch. Georgetown, TX: R. G. Landes Co.

Hirling, H., Henderson, B. R. \& Kuhn, L. C. (1994). Mutational analysis of the $[4 \mathrm{Fe}-4 \mathrm{~S}]$ cluster converting iron regulatory factor from its RNA-binding form to cytoplasmic aconitase. EMBO J 13, 453-461.

Kennedy, M. C. \& Beinert, H. (1988). The state of cluster SH and $\mathrm{S}^{2-}$ of aconitase during cluster interconversions and removal. $J$ Biol Chem 263, 8194-8198.

Kennedy, M. C., Emptage, M. H., Dreyer, J.-L. \& Bienert, H. (1983). The role of iron in the activation-inactivation of aconitase. J Biol Chem 258, 11098-11105.
Kim, H.-Y., Lavaute, T., Iwai, K., Klausner, R. D. \& Rouault, T. A. (1996). Identification of a conserved and functional iron-responsive element in the $5^{\prime}$-untranslated region of mammalian mitochondrial aconitase. J Biol Chem 271, 24226-24230.

Klausner, R. D. \& Rouault, T. A. (1993). A double life: cytosolic aconitase as a regulatory RNA binding protein. Mol Biol Cell 4, $1-5$.

Kushner, S. R. (1996). mRNA decay. In Esherichia coli and Salmonella: Cellular and Molecular Biology, pp. 849-860. Edited by F. C. Neidhardt and others. Washington, DC: American Society for Microbiology.

Mengaud, J. M. \& Horwitz, M. A. (1993). The major ironcontaining protein of Legionella pneumophila is an aconitase homologous with the human iron-responsive element-binding protein. J Bacteriol 175, 5666-5676.

Pantopoulos, K. \& Hentze, M. W. (1995a). Nitric oxide signaling to iron-regulatory protein: direct control of ferritin mRNA translation and transferrin receptor mRNA stability in transfected fibroblasts. Proc Natl Acad Sci USA 92, 1267-1271.

Pantopoulos, K. \& Hentze, M. W. (1995b). Rapid responses to oxidative stress mediated by iron regulatory protein. EMBO J 14, 2917-2924.

Prodromou, C., Haynes, M. J. \& Guest, J. R. (1991). The aconitase of Escherichia coli: purification of the enzyme and molecular cloning and map location of the gene (acn). J Gen Microbiol 137, 2505-2515.

Prodromou, C., Artymiuk, P. J. \& Guest, J. R. (1992). The aconitase of Escherichia coli. Eur J Biochem 204, 599-609.

Robbins, A. H. \& Stout, C. D. (1989). The structure of aconitase. Proteins 5, 289-312.

Rouault, T. A. \& Klausner, R. D. (1996). Iron-sulfur clusters as biosensors of oxidants and iron. Trend Biochem Sci 21, 174-177.

Sambrook, J., Fritsch, E. F. \& Maniatis, T. (1989). Molecular Cloning: a Laboratory Manual. Cold Spring Harbor, NY: Cold Spring Harbor Laboratory.

Silhavy, T. J., Barman, M. L. \& Enquist, L. W. (1984). Experiments with Gene Fusions. Cold Spring Harbor, NY: Cold Spring Harbor Laboratory.

Wilson, T. J. G., Bertrand, N., Tang, J.-L., Feng, J.-X., Pan, M.-Q., Barber, C. E., Dow, J. M. \& Daniels, M. J. (1998). The $r p f A$ gene of Xanthomonas campestris pathovar campestris, which is involved in the regulation of pathogenicity factor production, encodes an aconitase. Mol Microbiol 28, 961-970.

Received 11 June 1999; revised 27 July 1999; accepted 2 August 1999. 